Erhard HW, Price EO, Dally MR. 1998. Competitive ability of rams selected for high and low levels of sexual performance. Anim Sci 66:403-8.

Estep DQ, Price EO, Wallach SJ, et al. 1989. Social preferences of domestic ewes for rams (Ovis aries). Appl Anim Behav Sci 24:287-300.

Lasslo LL, Bradford GE. Torell DT, et al. 1985a. Selection for weaning weight in Targhee sheep in two environments. I. Direct response. J Anim Sci 61:376-86.

Lasslo LL, Bradford GE, Torell DT, et al. 1985b. Selection for weaning weight in Targhee sheep in two environments. II. Correlated effects. J Anim Sci 61:387-409.

Martin NL, Price EO, Wallach SJ, Dally MR. 1987. Fostering lambs by odor transfer: The add-on experiment. J Anim Sci 64:1378-83.

Price EO, Borgwardt R, Blackshaw JK, et al. 1994. Effect of early experience on the sexual performance of yearling rams. Appl Anim Behav Sci 42:41-8.

Price EO, Borgwardt R, Dally MR, et al. 1996. Repeated matings with individual ewes by rams differing in sexual performance. J Anim Sci

74:542-4.

Price EO, Borgwardt R. Dally MR. 1999. Effect of early fenceline exposure to estrous ewes on the sexual performance of yearling rams. Appl Anim Behav Sci 64:241-7.

Price EO, Dally MR,

Erhard HW, et al. 1998.

Manipulating odor cues

facilitates add-on fostering

in sheep. J Anim Sci

76:961-4

Price EO, Dunbar JM, Dally MR. 1984. Behavior of ewes and lambs subjected to restraint fostering. J Anim Sci 58:1084-9.

Price EO, Dunn GC, Talbot JA, et al. 1984. Fostering lambs by odor transfer: The substitution experiment. J Anim Sci 59:301-7.

Price EO. Estep DQ, Wallach SJ, et al. 1991. Sexual performance of rams as determined by maturation and sexual experience. J Anim Sci 69:1047-52.

Sakul H, Bradford GE, BonDurant RH, et al. 1993. Cryopreservation of embryos as a means of germ plasm conservation in sheep. Theriogenol 39:401-9.

Sakul H, Bradford GE, Dally MR. 1999. Selection for litter size or weaning weight in range sheep: I. Selection practiced and direct response. Sheep Goat Res J 15:122-33.

Sakul H, Dally MR, Bradford GE. 1993. Evaluation of Australian merino and U.S. sheep breeds for feed and carcass traits. $J$ Anim Sci 71:363-8.

Tomlinson KA, Price EO, Torell DT. 1982 Responses of tranquilized postpartum ewes to alien lambs. Appl Anim Ethol 8:109-17.

\title{
Is there a sire-dam interaction in sperm fertilizing potential?
}

Trish Berger a Martin R. Dally

TO optimize the efficiency of food animal production, a high level of reproductive efficiency is required because producers must spend a large proportion of their resources on the breeding herd. Previous research has demonstrated significant variation in the fertility of males. Our project was designed to evaluate whether there is a malefemale interaction in the fertilizing potential of sheep sperm.

The fertilizing potential of sperm is based on characteristics of the semen, or on the interaction of semen characteristics with those of the female reproductive tract, or both. To the extent that the fertilizing potential of sperm is based on the interaction with characteristics of the female reproductive tract, fertility is femaledependent (that is, there is a male-female interaction). These possibilities were tested by inseminating individual ewes with equal numbers of cryopreserved sperm from the same two rams in two consecutive breeding seasons.

Estrus was synchronized in five groups of approximately 30 Targhee-type white-faced ewes using progesterone-impregnated vaginal sponges. The ewes were inseminated with a mix of equal numbers of sperm from one of five different combinations of Merino and Suffolk rams. Ewes that lambed the first year were inseminated in the second year with the same combination of cryopreserved semen. The sire of each lamb was determined based on the coat color of the offspring's head and legs. The percentage of lambs sired by each male was determined for each semen combination using all lambs born to obtain an evaluation of the fertilizing potential of the two sources of sperm in each combination. Some ewes produced lambs sired only by the more fertile ram, and some gave birth to offspring sired only by the less fertile ram, or both. Ewes were divided into subgroups based on the sire or sires of lambs born the first year. The proportion of lambs sired by each male for these same ewes in the second breeding season was examined in the subgroups.

A total of 45 to 70 lambs (from 18 to 22 ewes) was born to each of the five combinations of sire semen. The more fertile semen in the combination produced $73 \%$ to $82 \%$ of the offspring. Twelve to 15 ewes in each of the five groups lambed twice to their respective semen combination. With a sireewe interaction, ewes conceiving to the more fertile semen the first year would be more likely (than the flock average) to conceive to that same semen the second year. Similarly, ewes conceiving to the less fertile semen the first year would be more likely to conceive to that same semen the second year. However, when ratios of lambs born the second year in the various subgroups were compared with ratios of lambs born the first year in those same subgroups, five of the 10 subgroups varied significantly $(P<0.01$ to $P<0.001)$. The lack of a sire-ewe interaction in this study suggests that the factors influencing the fertilizing potential of sperm are specific to the sperm rather than to the interaction with the female reproductive tract.

T. Berger is Professor, Department of Animal Science, UC Davis; and M.R. Dally is Staff Research Associate, Department of Animal Science, HREC. 